\title{
A NEW SPECIES OF JUNIPEROXYLON FROM THE EARLY MIOCENE OF NORTHWESTERN TURKEY
}

\author{
Ünal Akkemik
}

Received: 25 August 2020 / Accepted: 16 October 2020 / Published online: 29 October 2020

\begin{abstract}
Many different Cupressaceae species were described from the early Miocene of Turkey. Particularly, Glyptostroboxylon Conventz, 1885 and Taxodioxylon Hartig, 1848 from Cupressaceae are the most common genera. With the present study, a new fossil Juniperoxylon (Houlbert, 1910) Kräusel, 1949 species from early Miocene of northwestern Turkey was described as Juniperoxylon acarcaea Akkemik sp. nov. The new species has diffuse and zonate axial parenchyma, 2-3 (5) cupressoid pits per cross-field, sometimes presence of crassulae, uniseriate to biseriate, opposite, frequent, contiguous and sometimes spaced radial wall pits, even uniseriate and irregularly or alternately biseriate pits on tangential walls, horizontal walls of rays smooth and/or pitted, ray width uniseriate and rarely partly biseriate, and end walls of axial parenchyma nodular and smooth. The new species is the first Juniperoxylon species description from Turkey. According to the vegetation units (VU), this fossil species may indicate the forest was likely well-drained lowland and/or upland conifer forest (VU7).
\end{abstract}

Keywords: New species, Juniperoxylon, Juniperoxylon acarcaea, Galatian Volcanic Province, Turkey

\section{INTRODUCTION}

The Galatian Volcanic Province (GVP) is a rather important area due to having many fossil wood sites from Miocene age, particularly early Miocene and the late Miocene. Akkemik et al. (2009, 2016, 2017), Acarca Bayam et al. (2018), and Akkemik and Acarca Bayam (2019) identified many different fossil genera from this volcanic province. The forest types in the region may be separated as riparian, swamp, and well-drained lowland open mixed forests, and conifer forests (Akkemik et al., 2016; Denk et al., 2017; Güner et al., 2017; Acarca Bayam et al., 2018). Microfossils (Karayiğit et al., 1999; Yavuz-Işık, 2008; Yavuz-Işık and Demirci, 2009) and macrofossils (Kasapligil, 1977; Denk et al., 2017) from GVP also showed a rich forest vegetation. Within this woody flora, the genus of Juniperus L. was described in two different fossil sites, Hoçaş and Aşağıgüney fossil sites. In both Hoçaş and Aşağıgüney fossil sites, the juniper trees are represented with in-situ and large silicified stems.

Philippe and Bamford (2008) stated that neither real diagnosis nor description was given in the protologue by Houlbert (1910) for Juniperoxylon, and they used the Kräusel protologue (1949): "Conifer wood, cross-field pits in earlywood with oblique more or less narrow pores. Ray cell walls, at least the terminal ones, more or less strongly pitted (juniperoid pitting). Axial resiniferous parenchyma abundant, traumatic wood ever with resin pockets". Later, Ruiz and Bodnar (2019) made a valuable revision on Juniperoxylon. Until now, 11 Juniperoxylon species were described from mid-Triassic to Miocene in the world (Ruiz and Bodnar, 2019). In Turkey, Juniperoxylon is known from two fossil sites (Akkemik et al., 2016; Acarca Bayam et al., 2018). The purpose of the present study is to describe new fossil species from these materials, which are important elements of GVP and to discuss their potential affinities and growing site conditions.

\section{MATERIAL AND METHODS}

\section{Location fossil sites and a brief geology of the area}

The fossil areas are Aşağıgüney Fossil Site (Acarca Bayam et al., 2018) near Aşağıüney Village of the city Beypazarı in the province of Ankara and Hoçaş Fossil Site (Akkemik et al., 2016) near Hoçaş Village of the city of Seben in the province of Bolu (Fig. 1). The autochthonous fossil stems are found in both two sites. The detailed geology of the sites was given in Acarca Bayam et al. (2018, p.2-3, Fig.2). Both fossil sites are of early Miocene aged and belong to Hançili Formation in the Galatian Volcanic Province (Fig. 1). The Galatia Massif is generally Miocene in age and has units formed in a wide range from Early Miocene to Late Miocene. K/Ar aging of the volcanic rocks showed three phases (Keller et al., 1992; Türkecan et al., 1991; Toprak et al., 1996), as early Miocene (Phase 1), early-middle Miocene (Phase 2) and late Miocene (Phase 3). Paleontological findings are also in agreement with these ages (Akyürek, 1981; Yağmurlu et al., 1987; Irkeç and Ünlü, 1993; Keller et al., 1992). The fossil areas in this study fall into the early Miocene. The generalized stratigraphic column (from Akbaş et al., 2002) showed that fossiliferous part is Hançili Formation with early Miocene age. Early-Middle Miocene aged volcanics and intricate Hançili Formation and Late Miocene lacustrine Uruş Formation unconformably overlie the aged units. Pliocene aged Örencik Formation and Quaternary aged sediments constitute the youngest rock units of the region (Fig. 1) (Akbaş et al., 2002). 


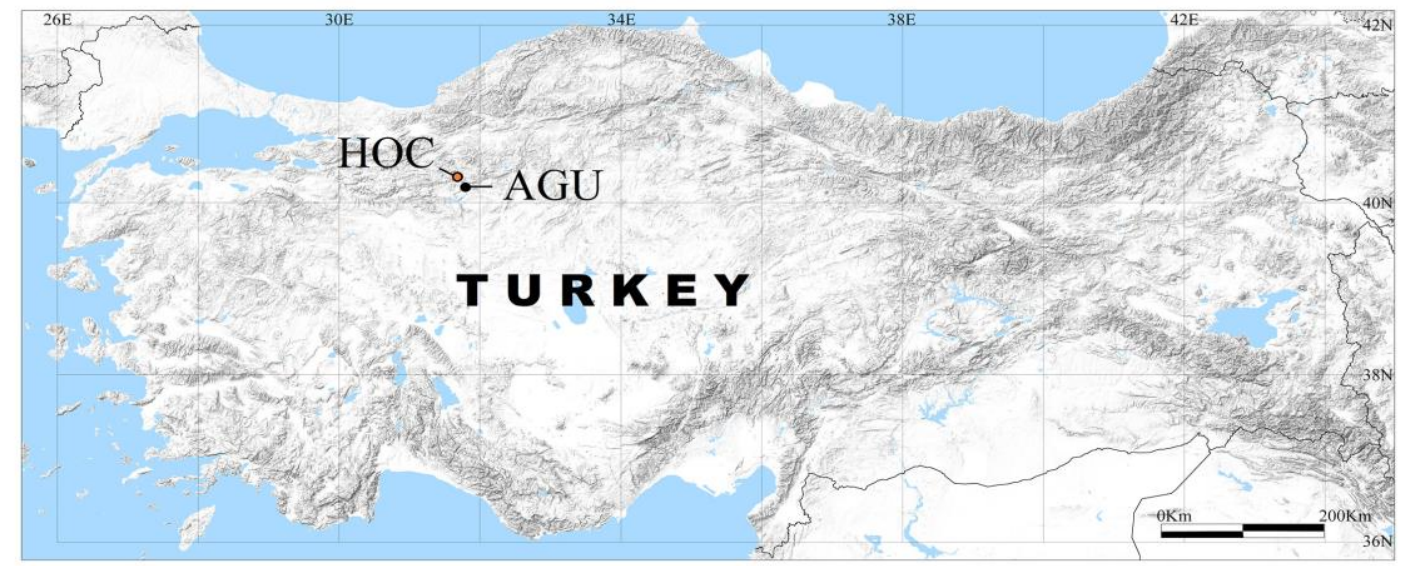

HOC: Hoçaş Fossil Site, Seben-Bolu (Akkemik et al., 2016)

AGU: Aşağıgüney Fossil Site, Beypazarı-Ankara (Acarca Bayam et al., 2018) and the present study.

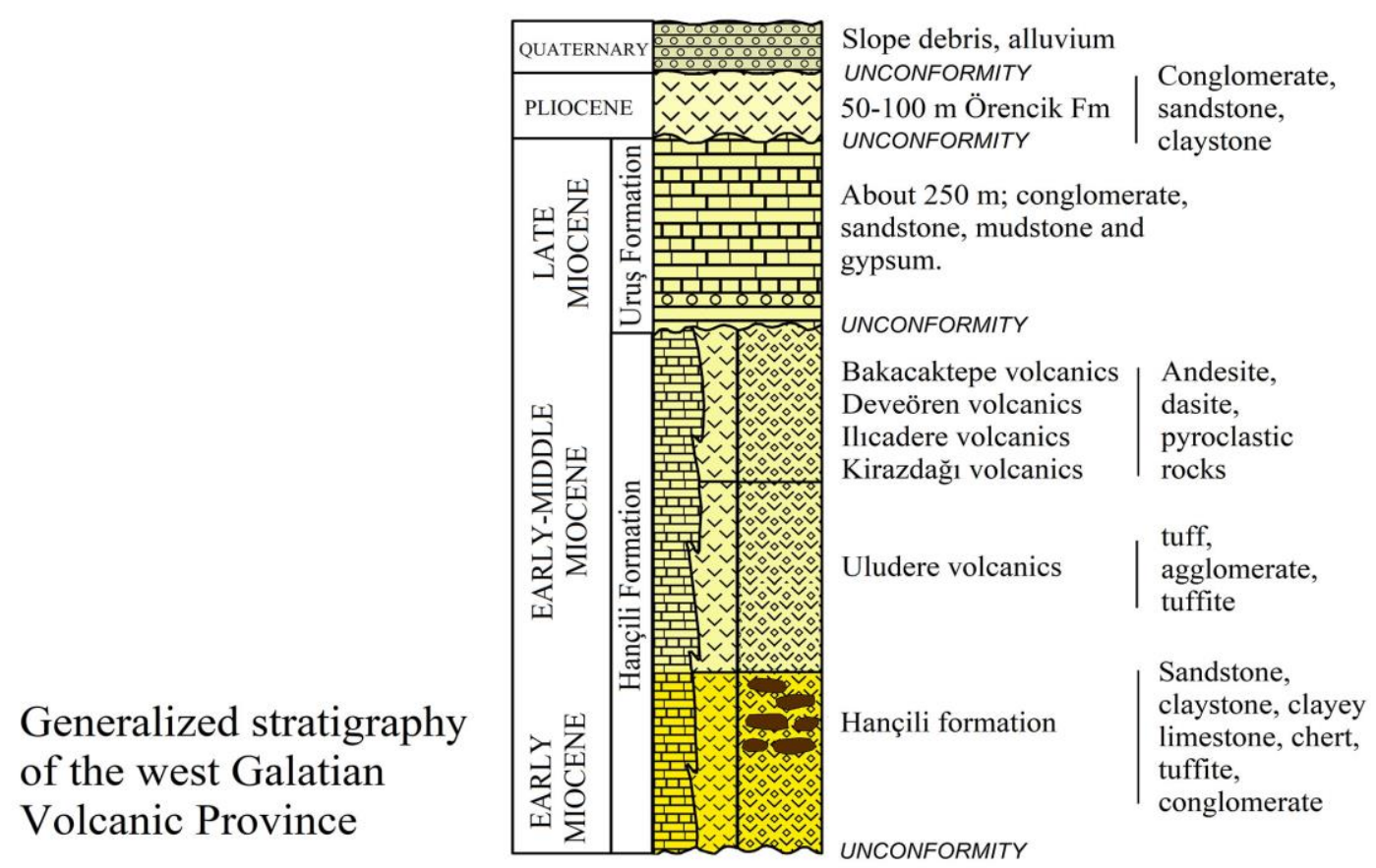

Fig. 1 The location map of the studies samples in Turkey, and the generalized stratigraphic section of the region covering the western parts of the Galatia Massif (Akbaş et al., 2002) and zone of fossils (Hançili Formation). The detailed geological structure of the area was given in Akkemik et al. (2016) and Acarca Bayam et al. (2018).

\section{Materials and wood identification}

The materials used in fossil species description were the thin sections housed at the Department of Forest Botany, Faculty of Forestry, Istanbul UniversityCerrahpasa.

In the analysis on species-level description, the woods from Hoçaş Fossil Site (HOC86, HOC90, HOC92, HOC93, HOC94, HOC95) (Akkemik et al. (2016) and Aşağıgüney Fossil Site (AGU04, AGU05, AGU09, AGU11, AGUD03, AGUD07, AGUD08, AGUD10) (Acarca Bayam et al. (2018) were used. These fossil woods were identified as Juniperus by Akkemik et al. (2016) and Acarca Bayam et al. (2018). Within these wood specimens AGUD08 (Fig. 2) was selected as holotype and identified as a new fossil Juniperoxylon species.
In identification on thin sections, reference samples and published papers (e.g. Houlbert, 1910; Stopes, 1915; Eckhold, 1923; Kräusel, 1920, 1949; Stockmans and Wileière, 1934; Grambast, 1954; Bonetti, 1966; Huard, 1966; Van der Burgh, 1973; Watari and Nishida, 1973; Süss and Rathner, 1998; Bodnar and Artabe, 2007; Kłusek, 2014; Akkemik et al., 2016; Dolezych, 2016; Acarca Bayam et al., 2018; Ruiz and Bodnar, 2019) were used, and the criteria of IAWA Committee (IAWA Committee, 2004) for softwood identification were followed. 


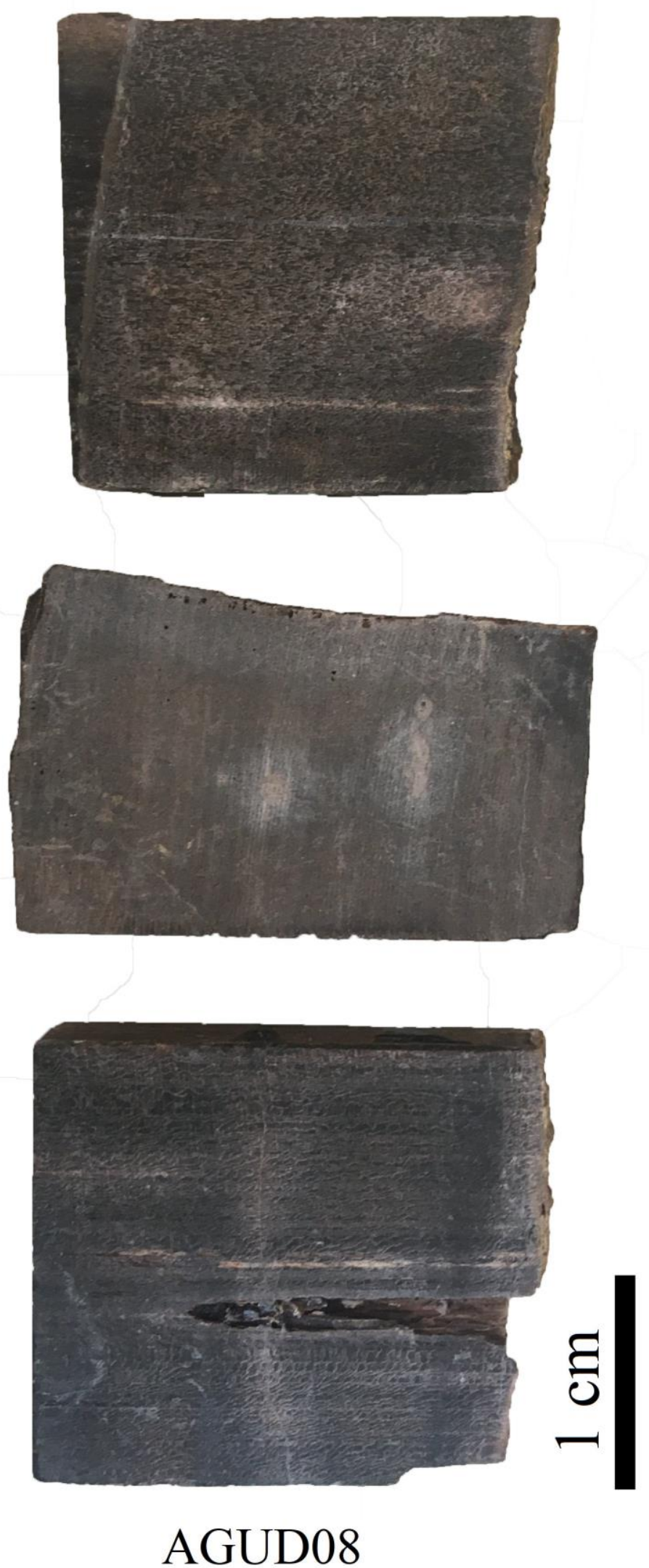

Fig. 2 The type specimen (AGUD08). These are remaining pieces from AGUD08 after taking three thin sections and storied at the Department of Forest Botany, Faculty of Forestry, Istanbul University-Cerrahpasa. 


\section{SYSTEMATIC PALAEBOTANY}

Order PINALES Gorozhankin, 1904

Family CUPRESSACEAE Gray, 1822

Genus JUNIPEROXYLON (Houlbert) Kräusel, 1949

Juniperoxylon acarcaea Akkemik sp. nov.

Figs. 2-5

Holotype. AGUD08.

Repository. The Department of Forest Botany, Faculty of Forestry, Istanbul University-Cerrahpasa, Istanbul, Turkey.

Etymology. The epithet "acarcaea" originates from the surname of Dr. N. Neslihan Acarca Bayam who worked on the petrified woods in the Galatian Volcanic Province for her $\mathrm{PhD}$ in Turkey. It was the first $\mathrm{PhD}$ on petrified woods in Turkey.

Plant Fossil Names Registry Number: PFN001814

Type locality. Aşağıgüney Village of the city of Beypazarı in the province of Ankara (AGU). This region is called Galatian Volcanic Province (GPV) (Fig. 1).

Age. Early Miocene.

Type horizon. Hançili Formation.

Diagnosis: Growth ring boundaries distinct with 2-3 rows of flattened latewood tracheids. False rings commonly present. Transition from earlywood to latewood indistinct. Tracheids generally circular, and intercellular spaces clearly obvious and occur throughout the wood. Normal axial resin canals absent. Axial parenchyma appears both diffuse (in the transition from earlywood to latewood and within the latewood itself) and tangentially zonate. Rays uniseriate, and sometimes partly biseriate. Ray height is 1-6 (max.16) cells. Tracheidal pits on tangential walls common and 1-2 seriate, irregular or slightly alternate. The rays with one cell height conspicuously longer. Transverse end walls of axial parenchyma cells are nodular and smooth. Ray tracheids absent. End walls of ray parenchyma cells nodular and smooth, horizontal walls of rays sparsely pitted. Tracheid pitting in radial walls of the earlywood is uniseriate and biseriate, opposite, frequent, contiguous, and sometimes spaced. Cross-field pitting is cupressoid with 2-3 (-5) pits per cross-field.
Description: Wood anatomical characteristics of the specimen of Juniperoxylon were given as follows:

Transversal section: Growth ring boundaries distinct with 2-3 rows of flattened latewood tracheids. False rings commonly present (Fig. 3: a-c). Transition from earlywood to latewood gradual and indistinct. Tracheids generally circular, and intercellular spaces clearly obvious and occur throughout the wood. Normal axial resin canals absent. Axial parenchyma presents and both diffuse (in the transition from earlywood to latewood and within the latewood itself) and tangentially zonate (Fig. 3: b (arrows)-c).

Tangential section: Rays exclusively uniseriate, and sometimes partly biseriate (Fig. 3: d). Ray height is 26 (max.16) cells (Fig. 3: d-e and Fig. 4: a). Tracheidal pits on tangential walls commonly present, and uni- to biseriate, irregularly spaced or slightly alternate (Fig. 3: e-f). The rays with one cell height conspicuously longer (Fig. 3: d-e). Transverse end walls of axial parenchyma cells are nodular and smooth (Fig. 4: b-d).

Radial section: Ray tracheids absent. Tracheid pitting in radial walls of the earlywood is uniseriate and biseriate, opposite, frequent, contiguous (Fig. 4: e-f), and sometimes spaced (Fig. 5: c). Crassulae sometimes presents (Figure 4: f). End walls of ray parenchyma cells nodular and smooth, and horizontal walls of rays sparsely pitted (Figure 5: a-d). Indenture rarely visible (Figure 5d). Cross-field pitting is cupressoid with 2-3 (-5) pits per cross-field (Fig. 5: e-g).

Discussion: According to the discussion by Ruiz and Bodnar (2019), the features of distinct growth ring boundary, narrow latewood band, common spaces among tracheid, presence of pits on tangential walls of tracheids, presence of diffuse and/or zonate axial parenchyma, cupressoid or taxodioid type of cross field pits, low height of rays, generally nodular end walls of axial parenchyma, and homocellular rays are the main characteristics of Juniperoxylon. Due to having very close wood anatomical characteristics with Ruiz and Bodnar (2019)'s description, the present fossil specimen was identified as Juniperoxylon. Based on the differences in the characteristics of the fossil species (Table 1), the following identification key was prepared to find the exact place of the present Juniperoxylon species:

\section{A. Ray tracheids present}

2A. Cross-field pits 4-6 cupressoid; end walls of axial parenchyma cells smooth; radial tracheidal pitting spaced and contiguous > Protojuniperoxylon ischigualastense Bonetti, 1966 emend. Bodnar \& Artabe, 2007

2B. Cross-field pits 1-3 cupressoid and taxodioid; end walls of axial parenchyma nodular; radial tracheidal pits sparse> Juniperoxylon rhenanum van der Burgh 1973

1B. Ray tracheids absent

3A. Axial parenchyma absent or scarce, if present, diffuse; Ray parenchyma horizontal walls smooth; 4-6 pits per cross-field; radial tracheidal pitting spaced and contiguous > Protojuniperoxylon maidstonense (Stopes, 1915) Eckhold, 1923 
3B. Axial parenchyma common.

4A. Zonate axial parenchyma present

5A. Cross-field pits only taxodioid; 2-6 pits per cross-field; end walls of axial parenchyma smooth or irregularly pitted; ray height 1-14 cells; horizontal end walls of rays smooth or rarely pitted > Juniperoxylon breviparenchmatosum Watari \& Nishida 1973

5B. Cross-field pits only cupressoid, and 1-6 per cross-field.

6A. Horizontal walls of rays smooth; ray width uniseriate and rarely partly biseriate; end walls of axial parenchyma smooth or nodular; radial wall pitting uniseriate, rarely bi-to triseriate pits opposite, and spaced > Juniperoxylon pachyderma (Göppert, 1850) Kräusel, 1949

6B. Horizontal walls of rays distinctly pitted.

7A. Radial wall pitting exclusively uniseriate, horizontal walls of rays distinctly pitted; ray width uniseriate; transversal end walls of axial parenchyma smooth > Juniperoxylon pottoniense (Stopes, 1915) Kräusel, 1949

7B. Radial wall pitting uni-to biseriate; transversal end walls of axial parenchyma nodular 8A. Tracheidal pits on radial walls often frequent and contiguous; rays uni- to biseriate; crassulae rarely present, end walls of axial parenchyma nodular and smooth; end walls of rays nodular and smooth; horizontal walls of rays sparsely pitted > Juniperoxylon acarcaea Akkemik sp.nov.

8B. Spacing of radial tracheidal pits sparse; rays uniseriate; crassulae present; ray parenchyma horizontal walls distinctly pitted > Juniperoxylon juniperoides (Kownas, 1951) Huard, 1966

4B. Zonate axial parenchyma absent, axial parenchyma only diffuse.

9A. Axial parenchyma scarce; ray heights 2-34 cells; ray parenchyma horizontal walls distinctly pitted; 1-2 (3-4) pits per cross-field; radial tracheidal pitting spaced but not contiguous > Juniperoxylon zamunerae (Bodnar et al., 2015) Ruiz \& Bodnar 2019

9B. Axial parenchyma present, abundant, and diffuse; ray height up to 18 cells.

10A. Ray parenchyma horizontal walls smooth; end walls of axial parenchyma cells nodular; ray heights 1-5 cells > Juniperoxylon wagneri Süss \& Rather 1998

10B. Ray parenchyma horizontal walls sparsely or distinctly pitted; Ray heights up to 18 cells.

$11 \mathrm{~A}$. Horizontal walls of ray parenchyma sparsely pitted; rays uniseriate and occasionally biseriate; axial parenchyma abundant; crassulae present > Juniperoxylon schneiderianum Dolezych 2016

11B. Horizontal walls of ray parenchyma distinctly pitted; rays uniseriate; axial parenchyma present; crassulae absent > Juniperoxylon turonense Houlbert, 1910

According to the identification key and the given characteristics in Table 1, the new fossil Juniperoxylon species has differences from all former fossil species.

Juniperoxylon zamunerae (Bodnar et al., 2015) Ruiz \& Bodnar, 2019 differs from the new species in having scarce and diffuse axial parenchyma, and 2-34 cells height of rays.

Protojuniperoxylon maidstonense (Stopes, 1915) Eckhold, 1923 differ from the present specimen in having scarce axial parenchyma and predominantly uniseriate tracheidal pitting on radial walls, and 4-6 cupressoid pits per cross-field (Bodnar and Artabe, 2007).

Juniperoxylon wagneri Süss \& Rather 1998, Protojuniperoxylon ischigualastense Bonetti, 1966 emend. Bodnar \& Artabe, 2007, and J. schneiderianum Dolezych, 2016 differ from the new specimen in having only diffuse axial parenchyma.

Juniperoxylon breviparenchmatosum Watari \& Nishida, 1973 differs from the new species in having only taxodioid type cross-field pits.

Juniperoxylon rhenanum van der Burgh, 1973 differs from the new species in having 1-3 cupressoid and taxodioid cross-field pits, space of radial tracheidal pits, much longer rays (1-40 cells), and crassulae formation. The closest fossil species are Juniperoxylon pachyderma (Göppert, 1850) Kräusel, 1949, J. juniperoides (Kownas,
1951) Huard, 1966, and J. pottoniense (Stopes, 1915) Kräusel, 1949. These three fossil species have only spaced radial tracheidal pits. The new fossil species has both spaced and contiguous radial tracheidal pits. $J$. pachyderma and J. juniperoides have also crassulae formation, and J. pottoniense has exclusively uniseriate pits on radial walls of tracheids.

Based on these differences, the specimen was described as a new Juniperoxylon species and named Juniperoxylon acarcaea Akkemik sp. nov. The descriptions of Juniperus from Hoçaş Fossil site (Akkemik et al., 2016) and from Aşağıgüney Fossil site (Acarca Bayam et al., 2018) were compared with the new species and results showed that they both had very similar features. It can be concluded that the new species, Juniperoxylon acarcae Akkemik sp.nov. has an area through the valley between Beypazarı-Aşağıgüney Village and Seben-Kozyaka Village (Fig. 1).

Affinities: The fossil Juniperoxylon descriptions (e.g.Vaudois and Privé, 1971; Bodnar and Artabe, 2007; Kłusek, 2014; Akkemik et al., 2016; Dolezych, 2016, Acarca Bayam et al., 2018) revealed that this type of wood is closely related to modern Cupressaceae due to the the presence of "abietinean tracheid pitting, distinctly pitted ray cell walls, axial parenchyma and cupressoid cross-fields". 

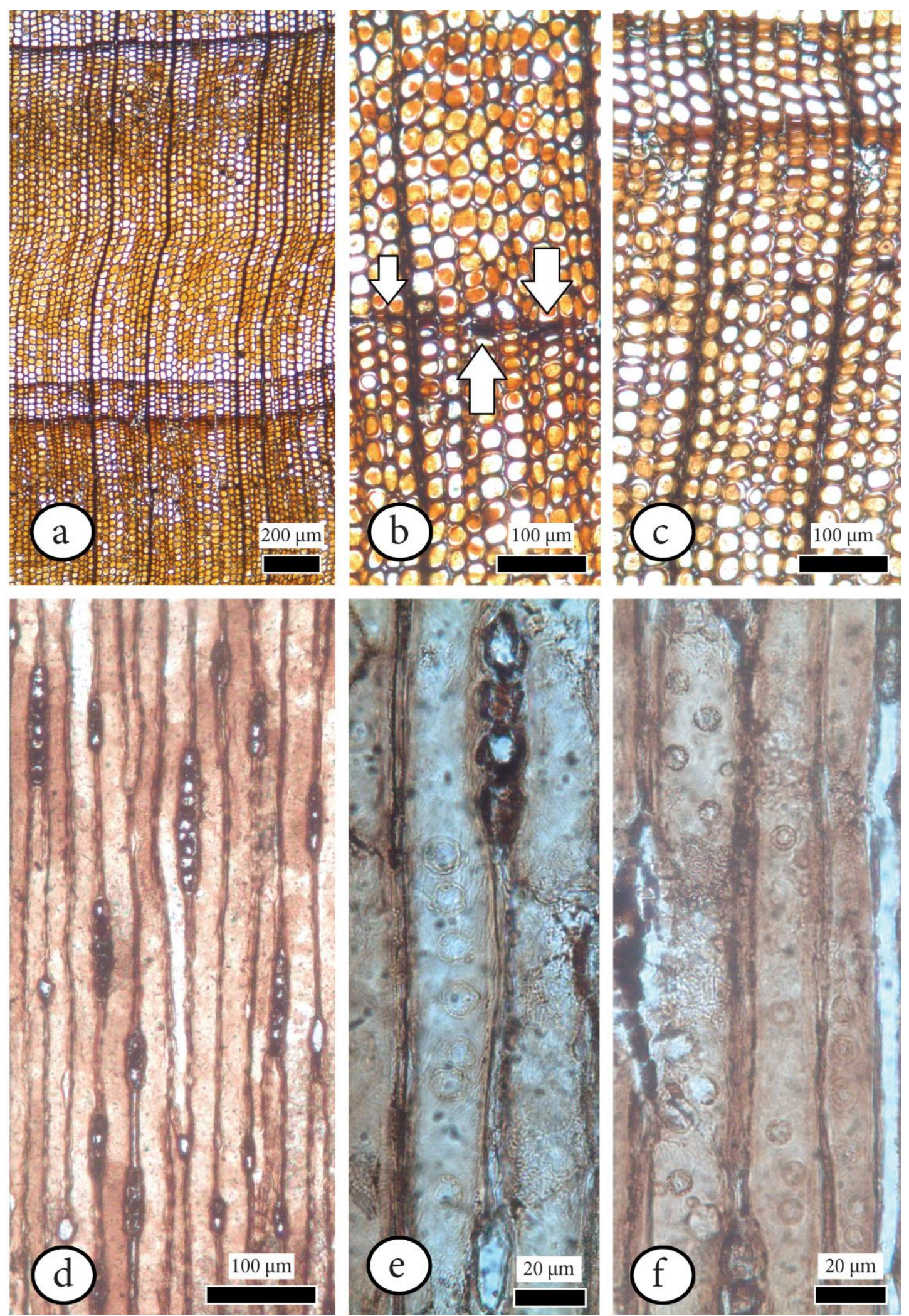

Fig. 3 The thin sections of Juniperoxylon acarcaea Akkemik sp. nov. a) Transversal section with false rings and without resin canals, b) Marginal (zonate) axial parenchyma (arrows) and spaces between tracheids, c) Spaces between tracheids, and diffuse axial parenchyma cells, d) Tangential section with uni-to partly biseriate rays, e) Uniseriate pits on tangential walls of tracheids, f) Biseriate and alternate pits on tangential walls of tracheids. 

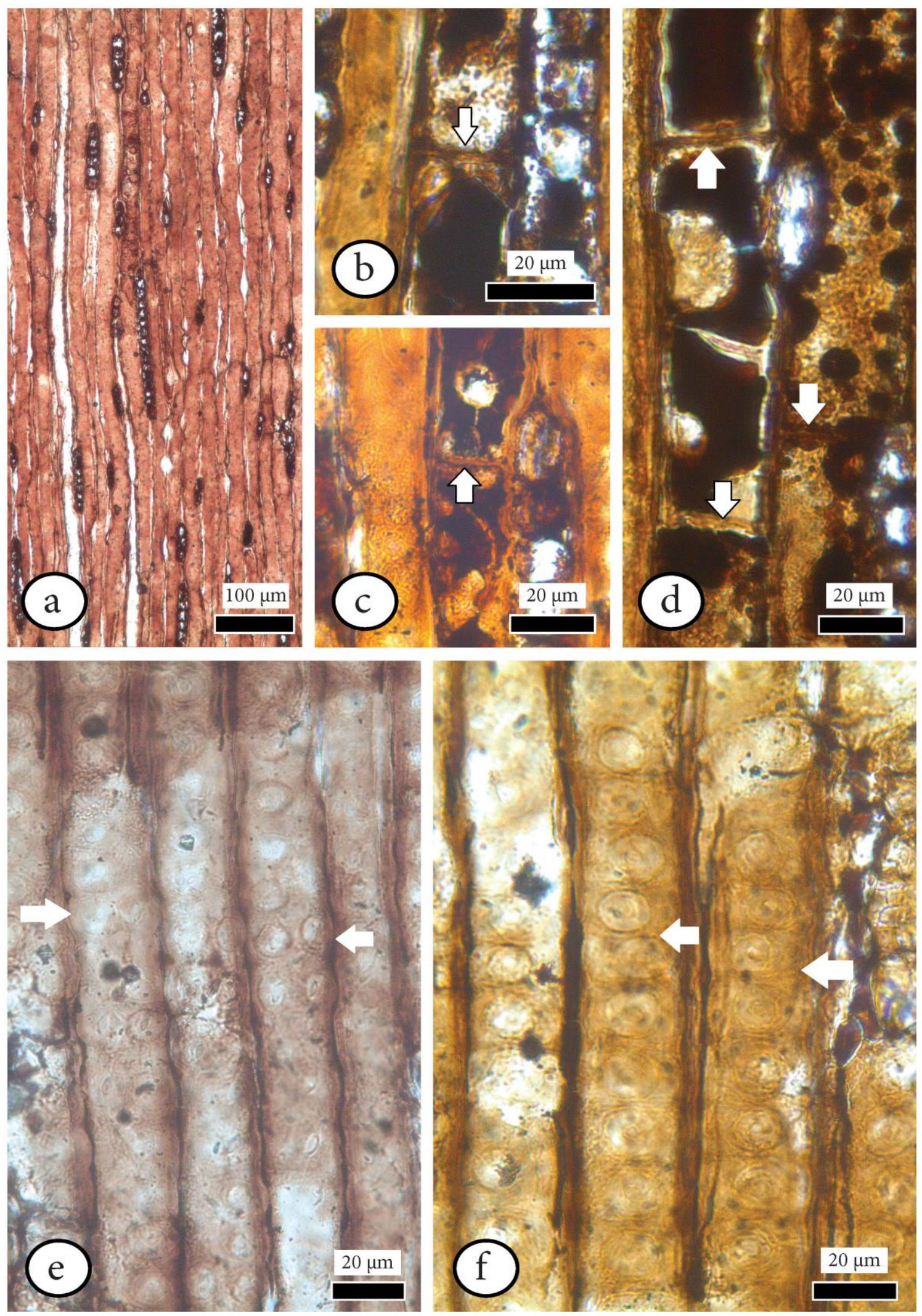

Fig. 4 The thin sections of Juniperoxylon acarcaea Akkemik sp. nov. a) Tangential section with short rays, b-d) Nodular and smooth end walls of axial parenchyma, e) Mostly uniseriate and sometimes biseriate pits on radial walls of tracheids (arrows), f) Frequent uniseriate pits and crassulae formation (arrows). 

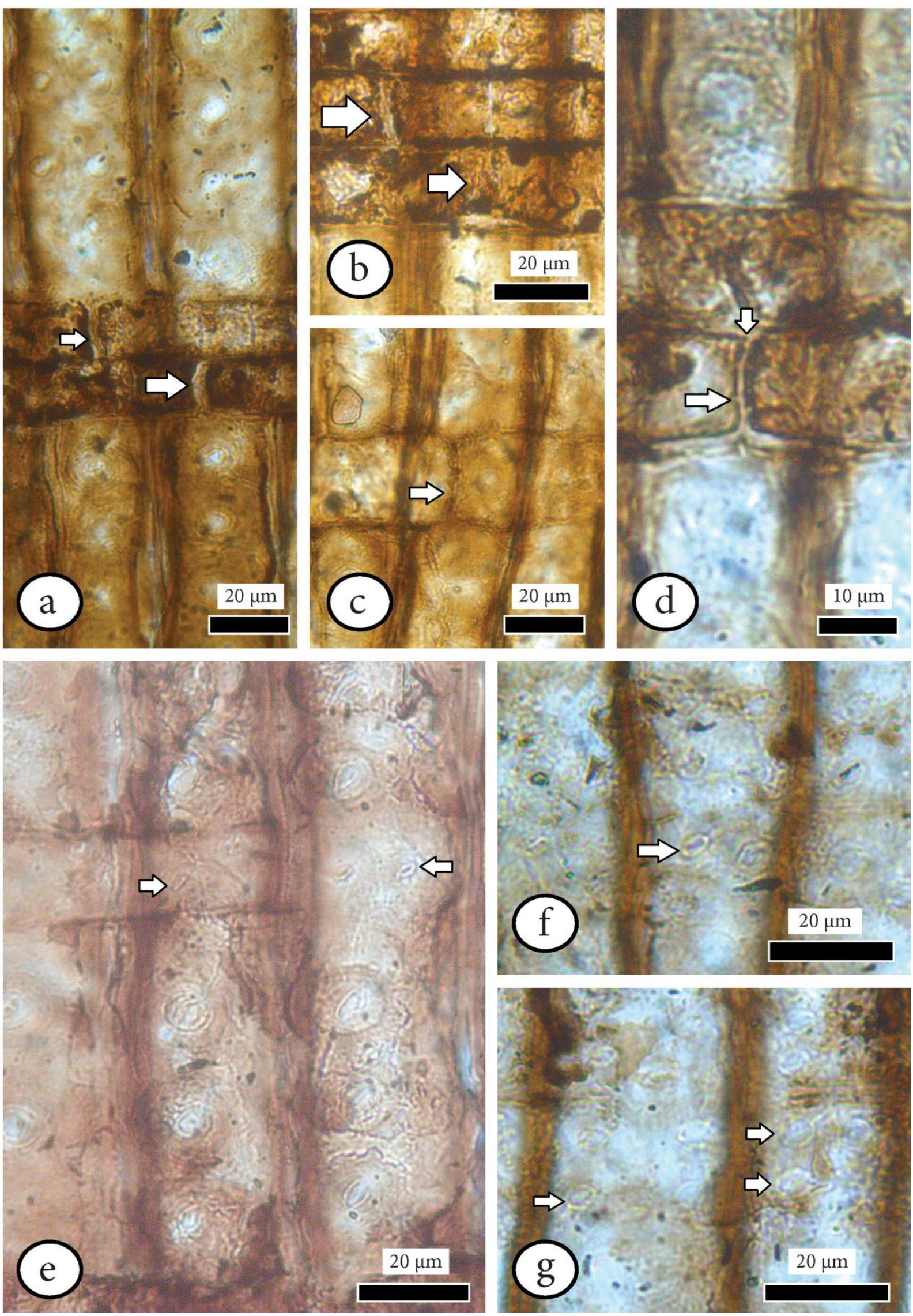

Fig. 5 The thin sections of Juniperoxylon acarcaea Akkemik sp. nov. a) Smooth end walls of rays (arrow), b-c) Slightly dentate end walls of ray, and sparsely pitted horizontal walls of rays, d) Indenture (vertical arrow) and sparsely nodular horizontal walls of rays (horizontal arrow), e-g) Cupressoid type cross-field pits, 2-5 pits per cross-field. 


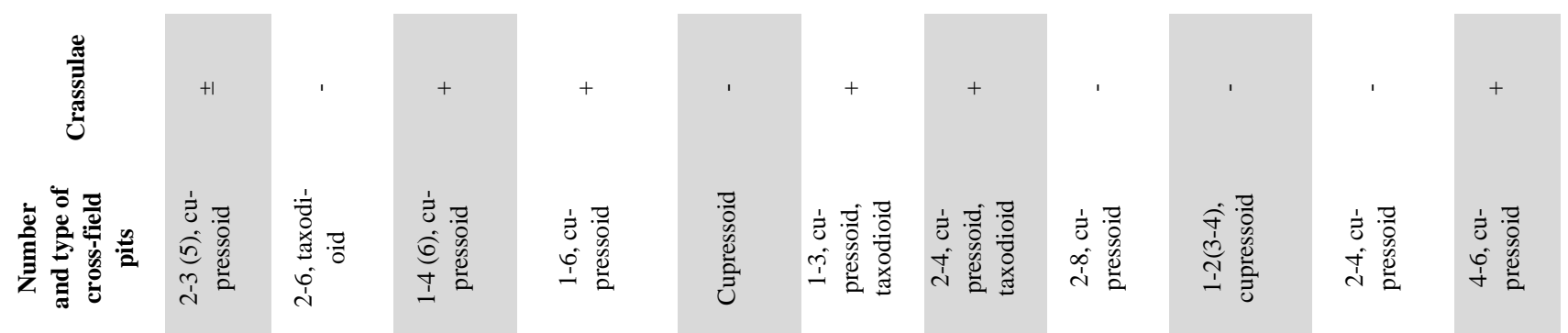

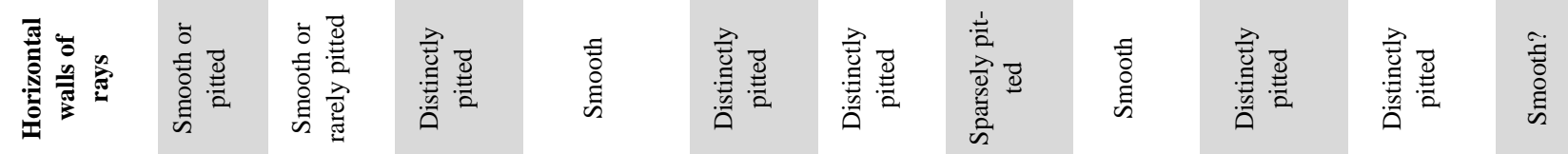

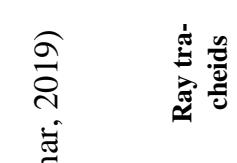

IIUI!

II

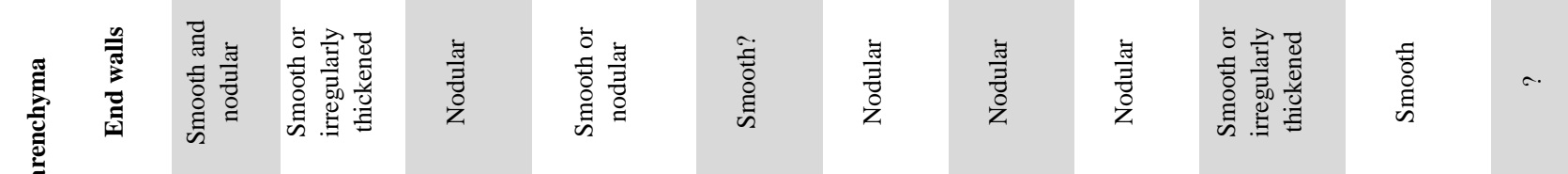

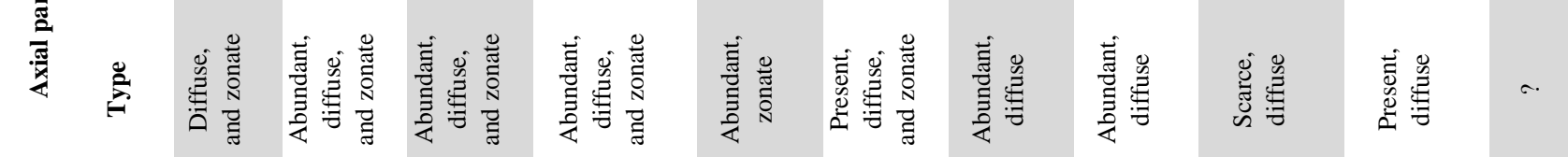

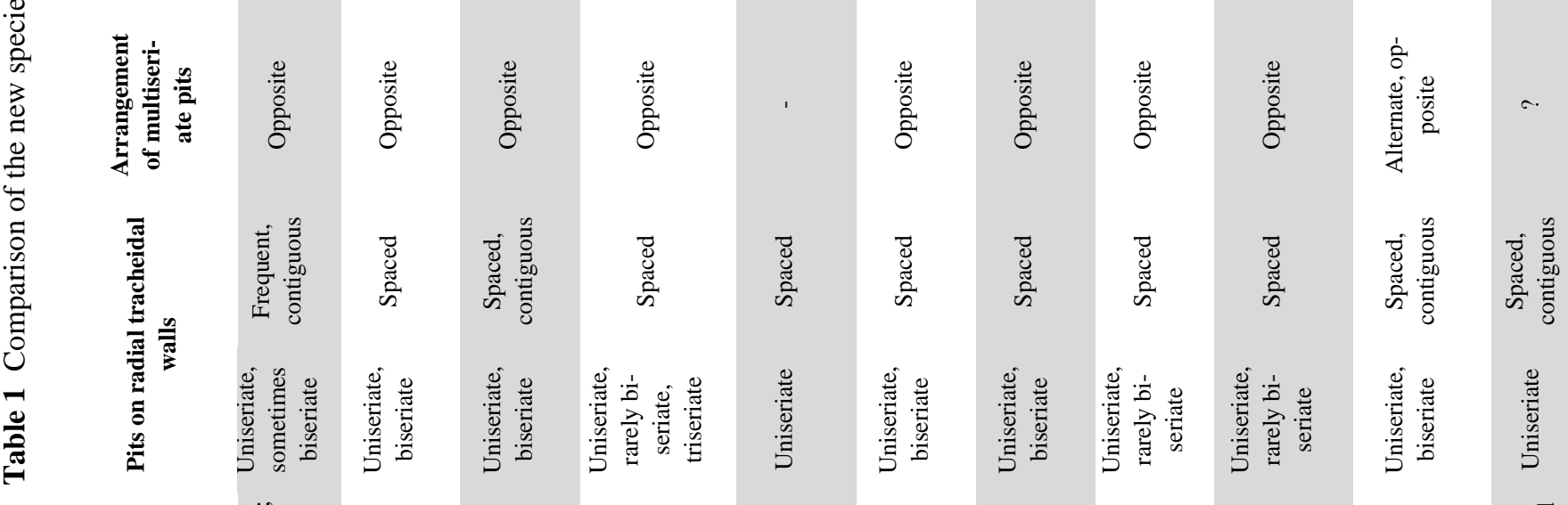

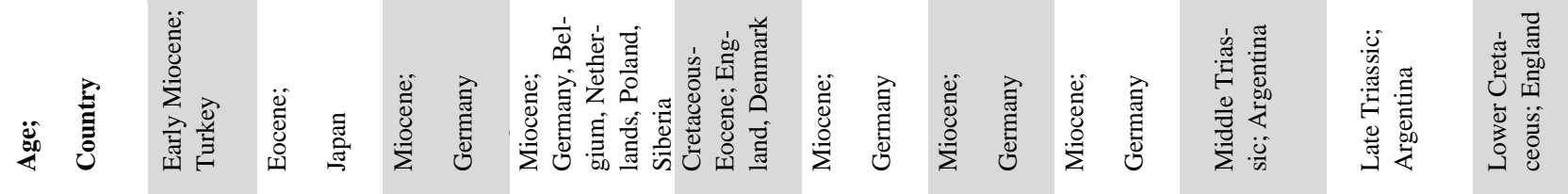

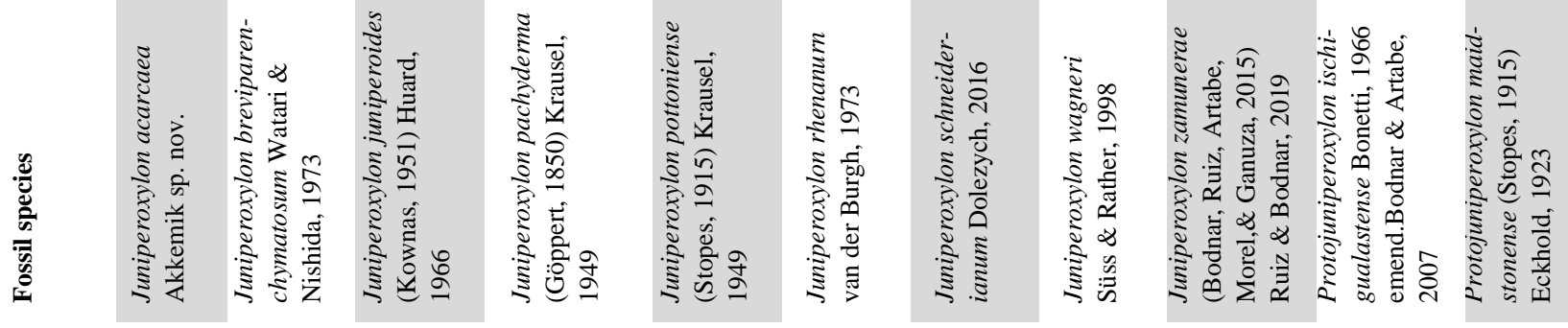


Table 2. Comparison of modern Juniperus species (Esteban et al., 2004; Akkemik and Yaman, 2012) and Juniperoxylon acarcaea sp. nov.

\begin{tabular}{|c|c|c|c|c|c|c|c|c|}
\hline $\begin{array}{l}\text { Fossil species } \\
\text { / } \\
\text { Features }\end{array}$ & $\begin{array}{l}\text { Juniperus } \\
\text { drupacea } \\
\text { Labill. }\end{array}$ & $\begin{array}{l}\text { Juniperus } \\
\text { excelsa } \\
\text { M.Bieb. }\end{array}$ & $\begin{array}{l}\text { Juniperus } \\
\text { foetidissima } \\
\text { Willd. }\end{array}$ & $\begin{array}{l}\text { Juniperus } \\
\text { oxycedrus } \mathbf{L} .\end{array}$ & $\begin{array}{l}\text { Juniperus } \\
\text { phoenicea } \mathrm{L} .\end{array}$ & $\begin{array}{l}\text { Juniperus sal- } \\
\text { tuaria Rehder } \\
\text { \& E.H.Wilson }\end{array}$ & $\begin{array}{l}\text { Juniperus } \\
\text { thurifera } \mathrm{L} .\end{array}$ & $\begin{array}{l}\text { Juniperoxylon } \\
\text { acarcaea } \\
\text { Akkemik sp. nov. }\end{array}$ \\
\hline $\begin{array}{l}\text { Growth } \\
\text { ring }\end{array}$ & Distinct & Distinct & Distinct & Distinct & Distinct & Distinct & Distinct & Distinct \\
\hline $\begin{array}{l}\text { Partial and } \\
\text { false ring }\end{array}$ & Present & Present & Present & Present & Present & Present & Present & Present \\
\hline $\begin{array}{l}\text { Transition } \\
\text { from ear- } \\
\text { lywood to } \\
\text { latewood }\end{array}$ & Gradual & Gradual & Gradual & $\begin{array}{l}\text { Gradual; } 2-3 \\
\text { seriate of } \\
\text { flattened } \\
\text { latewood } \\
\text { tracheids }\end{array}$ & Gradual & Gradual & Gradual & $\begin{array}{l}\text { Gradual; } 1-2 \\
\text { seriate of flattened } \\
\text { latewood tracheids }\end{array}$ \\
\hline $\begin{array}{l}\text { Radial } \\
\text { pitting }\end{array}$ & $\begin{array}{l}\text { Predominantly } \\
\text { uniseriate }\end{array}$ & $\begin{array}{l}\text { Predominantly } \\
\text { uniseriate }\end{array}$ & $\begin{array}{l}\text { Predominantly } \\
\text { uniseriate }\end{array}$ & $\begin{array}{l}\text { Predominantly } \\
\text { uniseriate }\end{array}$ & $\begin{array}{l}\text { Predominantly } \\
\text { uniseriate }\end{array}$ & $\begin{array}{l}\text { Predominantly } \\
\text { uniseriate }\end{array}$ & $\begin{array}{l}\text { Predominantly } \\
\text { uniseriate }\end{array}$ & $\begin{array}{l}\text { Uniseriate, } \\
\text { Sometimes biseri- } \\
\text { ate, opposite, } \\
\text { spaced and con- } \\
\text { tiguous }\end{array}$ \\
\hline $\begin{array}{l}\text { Intercellular } \\
\text { space }\end{array}$ & $\begin{array}{l}\text { Commonly } \\
\text { present }\end{array}$ & $\begin{array}{l}\text { Commonly } \\
\text { present }\end{array}$ & $\begin{array}{l}\text { Commonly } \\
\text { present }\end{array}$ & $\begin{array}{l}\text { Commonly } \\
\text { present }\end{array}$ & $\begin{array}{l}\text { Commonly } \\
\text { present }\end{array}$ & Present & Present & $\begin{array}{l}\text { Commonly pre- } \\
\text { sent }\end{array}$ \\
\hline $\begin{array}{l}\text { Helical thick- } \\
\text { ening }\end{array}$ & Absent & Absent & Absent & Absent & Absent & Absent & Absent & Absent \\
\hline $\begin{array}{l}\text { Latewood } \\
\text { tracheids }\end{array}$ & Thick walled & Thick walled & Thick walled & Thick walled & Thick walled & Thick walled & Thick walled & Thick walled \\
\hline $\begin{array}{l}\text { Axial paren- } \\
\text { chyma }\end{array}$ & Common & Common & Common & Common & Common & Common & Common & Common \\
\hline $\begin{array}{l}\text { Marginal } \\
\text { axial paren- } \\
\text { chyma }\end{array}$ & Absent & Present & Absent & Present & Absent & Absent & $\begin{array}{l}\text { Present and 1-3 } \\
\text { seriate }\end{array}$ & Present, uniseriate \\
\hline End walls & $\begin{array}{l}\text { Distinctly } \\
\text { pitted }\end{array}$ & $\begin{array}{l}\text { Distinctly } \\
\text { pitted }\end{array}$ & $\begin{array}{l}\text { Distinctly } \\
\text { pitted }\end{array}$ & $\begin{array}{l}\text { Distinctly } \\
\text { pitted }\end{array}$ & $\begin{array}{l}\text { Distinctly } \\
\text { pitted }\end{array}$ & $\begin{array}{l}\text { Smooth } \\
\text { Pitted }\end{array}$ & $\begin{array}{l}\text { Smooth } \\
\text { Pitted }\end{array}$ & Distinctly pitted \\
\hline Rays & $\begin{array}{l}\text { Exclusively } \\
\text { uniseriate, } \\
\text { rarely partly } \\
\text { biseriate }\end{array}$ & $\begin{array}{l}\text { Exclusively } \\
\text { uniseriate, } \\
\text { rarely partly } \\
\text { biseriate }\end{array}$ & $\begin{array}{l}\text { Exclusively } \\
\text { uniseriate, } \\
\text { rarely partly } \\
\text { biseriate }\end{array}$ & $\begin{array}{l}\text { Exclusively } \\
\text { uniseriate, } \\
\text { rarely partly } \\
\text { biseriate }\end{array}$ & $\begin{array}{l}\text { Exclusively } \\
\text { uniseriate, } \\
\text { rarely partly } \\
\text { biseriate }\end{array}$ & $\begin{array}{l}\text { Exclusively } \\
\text { uniseriate, } \\
\text { partly biseriate }\end{array}$ & Uniseriate & $\begin{array}{l}\text { Rays exclusively } \\
\text { uniseriate, rarely } \\
\text { partly biseriate. }\end{array}$ \\
\hline $\begin{array}{l}\text { End walls } \\
\text { of rays }\end{array}$ & Nodded & Nodded & Nodded & Nodded & Nodded & Nodded & Nodded & Nodded \\
\hline $\begin{array}{l}\text { Cross-field } \\
\text { pitting }\end{array}$ & Cupressoid & Cupressoid & $\begin{array}{l}\text { Cupressoid } \\
\text { and taxodioid }\end{array}$ & Cupressoid & Cupressoid & Cupressoid & Cupressoid & Cupressoid \\
\hline $\begin{array}{l}\text { Pit number } \\
\text { per } \\
\text { cross-field }\end{array}$ & $1-2(1-4)$ & $2(2-4)$ & $2(1-4)$ & $1-2(1-5)$ & $1-2(1-5)$ & $1-4$ & $1-4$ & $2-3(-5)$ \\
\hline Ray heights & $3(1-6)$ & $1-4(-13)$ & $1-11(-19)$ & $1-8(-19)$ & $1-7(-14)$ & $1-15$ & $1-15$ & $2-6(-16)$ \\
\hline Indenture & Present & Present & Present & Present & Present & Present & Absent & Present \\
\hline
\end{tabular}

In Cupressaceae, normal resin canals and helical thickenings are also absent. When some fossil species such as J. zamurense are related to different modern genera, Chamaecyparis Kurz., Cupressus L., Fitzroya Lindl. and Juniperus (Ruiz and Bodnar, 2019), the new species, Juniperoxylon acarcae, is closely related to the modern Juniperus. A comparison of the features of the new fossil species with the five modern Juniperus species in Turkey, which are native, and two similar species given in Esteban et al. (2004), which are Juniperus saltuaria Rehder et E.H. Wilson from south of China and Tibet and
Juniperus thurifera L. from the western Mediterranean Basin, showed the highest similarities. However, Juniperus foetidissima Willd. has both cupressoid and taxodioid cross-field pits, and Juniperus saltuaria has not marginal and metatraheal axial parenchyma, therefore, these two species slightly differ from the fossil species and the other five modern Mediterranean species (Table 2). Wood features demonstrated that both fossil and modern species are rather close to each other, and therefore, the fossil species may be evaluated as a possible ancestor of the modern species in the Mediterranean basin. 
Possible growing site conditions: The described Juniperoxylon acarcaea Akkemik sp. nov. is a forest tree of the Galatian Volcanic Province (GVP). The new species was one of the elements within a rich woody flora of GVP (Karayiğit et al., 1999; Yavuz-Işık, 2008; YavuzIşık and Demirci, 2009; Kasaplıgil, 1977; Denk et al., 2017; Akkemik et al., 2016; Acarca Bayam et al., 2018). The early Miocene trees of Pinus L., Juniperus, Cedrus Trew., Ulmus L., Zelkova Spach., Liquidambar L., and Acer L., grow under the conditions of VU0, and VU5 to VU7 in GVP. These vegetation units (VU) classify that VU0 is subtropical, moist or dry light forests, VU5 is well-drained lowland forests, VU6 is well-drained upland forests, and VU7 is well-drained (lowland and) upland conifer forest (Denk et al, 2017; Güner et al., 2017).

The Juniperoxylon acarcaea stems are autochthonous in the field. The other autochthonous early Miocene trees are Quercus Sect. Ilex, palms (later they were identified as Palmoxylon sp. cf. Trachycarpus by Iamandei et al., 2018), Liquidambar and Salix/Populus in Hoçaş Fossil Site (Akkemik et al., 2016). Because these fossil woods are found in their original positions in the field, to interpret their life conditions is more satisfactory. The presence of these riparian and lowland trees may suggest that the growing area of Juniperoxylon acarcaea trees was a forest having an open, well-drained lowland growing conditions.

\section{CONCLUSION}

The present study focusing on a new species description from the Galatian Volcanic Province suggested a new species, Juniperoxylon acarcaea. This is the first fossil species of the genus of Juniperoxylon from the early Miocene of Turkey. The wood anatomical characteristics reflected very close features to the modern five Mediterranean juniper species and more stable wood characteristics from the early Miocene to the present. This new species likely growslgrew under the growing site conditions of VU0 and VU7, which means that the region was an open and lowland coniferous forest. Today, the similar modern species such as Juniperus oxycedrus L., J. excelsa M. Bieb., J. foetidissima Willd., J. drupacea Labill., J. phoenicea L., and J. thurifera L. grow in open, lowland and upland conifer forests in the Mediterranean basin.

\section{ACKNOWLEDGEMENTS}

The specimen, which was re-examined in this study, was taken in the fieldtrips of the projects supported by the Research Fund of Istanbul University-Cerrahpasa Project Number: YÖP-41738 and 22800, and storied at the Department of Forest Botany, Faculty of Forestry, Istanbul University-Cerrahpasa. I thank Dr. Dimitra Mantzouka and Dr. Stănilă Iamandei for their reviewing the paper and their valuable comments.

\section{REFERENCES}

Acarca Bayam, N.N., Akkemik, Ü., Poole, I., \& Akarsu. F., 2018. Further Contributions to the early Miocene forest vegetation of the Galatean Volcanic Province, Turkey. Palaeobotanica Electronica, 21.3.40A 1-42. https://doi.org/10.26879/816palaeo-

electronica.org/content/2018/2353-trees-of-gvp-inmiocene

Akbaş, B., Sevin, M. \& Aksay, A. 2002. 1/100.000 scale Turkey Geology Maps No: 40. Bolu - H27 Section. MTA Jeoloji Etüdleri Dairesi, Ankara [in Turkish].

Akkemik, Ü. \& Yaman, B., 2012. Wood Anatomy of Eastern Mediterranean Species. Kessel Publishing House, Germany.

Akkemik, Ü., Acarca N.N., \& Hatipoğlu, M., 2017. The first Glyptostroboxylon from the Miocene of Turkey. IAWA Journal, 38(4):561-570. https://doi.org/10.1163/22941932-20170181

Akkemik, Ü., Arslan M., Poole I., Tosun, S., Köse, N., Karlıoğlu Kılıç, N. \& Aydın, A., 2016. Silicified woods from two previously undescribed early Miocene forest sites near Seben, northwest Turkey. Review of Palaeobotany and Palynology 235:31-50, https://doi.org/10.1016/j.revpalbo.2016.09.012

Akkemik, Ü., Atıcı, G., Poole, I. \& Çobankaya, M., 2018. Three new silicified woods from a newly discovered earliest Miocene forest site in the Haymana Basin (Ankara, Turkey). Review of Palaeobotany and Palynology, 254: 49-64.

Akkemik, Ü., Kıran Yıldırım, D., Sakala, J., Akkılıç, H. \& Altınışı, A., 2019a. New petrified wood descriptions from west-central Anatolia: contribution to the composition of the Neogene forest of Turkey. Neues Jahrbuch für Geologie und Paläontologie, Abh., 292(1):

$57-$

71.https://doi.org/10.1127/njgpa/2019/0808

Akkemik, Ü., Akkıllıc, H. \& Güngör, Y., 2019b. Fossil wood from the Neogene of the Kilyos coastal area in Istanbul, Turkey. Palaeontographica Abteilung B Palaeobotany - Palaeophytology. 299 (4-6): 133185

Akyürek, B. 1981. Basic geological features of the northern part of the Ankara Melange. Symposium on Geology of Inner Anatolia pp.41-48. 35th Scientific and Technical Meeting, Ankara [in Turkish].

Aytug, B. \& Şanlı, İ., 1974. Forêt de la fin du Tertiaire aux environs du Bosphore. Review of the Faculty of Forestry University of Istanbul, 24 (2-A): 64-78.

Bodnar, J. \& Artabe, A.E., 2007. Estudio sistemático y paleodendrológico del leño de una Cupressaceae triásica de la Formación Ischigualasto provincia de San Juan, Argentina. Ameghiniana, 44: 303-319.

Bonetti, M.I.R., 1966. Protojuniperoxylon ischigualastensis sp. nov. Del Triásico de Ischigualasto (San Juan). Ameghiniana 4: 211-218.

Dolezych, M., 2016. A remarkable extinct wood from Lusatia (central Europe) - Juniperoxylon schneideria- 
num sp. nov. with affinity to Cupressospermum saxonicum Mai. Palaeontographica B, 295: 5-31.

Eckhold, W., 1923. Die Hoftüpfel bei rezenten und fossilen Coniferen. Jahrbuch der preußischen geologischen Landesanstalt zu Berlin, 42:472-505.

Grambast, L., 1954. Un Juniperoxylon particulier de l'Eocène inférieur du Bassin de Paris. Archives du Muséum National du Paris, 3: 1-21.

Houlbert, C., 1910. Les bois des faluns de Touraine. Feuille des jeunes Naturalistes 40: 70-76.

Huard, J., 1966. Étude anatomique des bois de conifères des couches à lignite néogènes des Landes. Mémoires de la Société géologique de France 105: 1-85.

IAWA Committee, 2004. IAWA list of microscopic features for softwood identification. IAWA Journal, 25:1-70.

Irkeç, T., Ünlü, T. 1993. An example of hydrothermal sepiolite formation in volcanic belts: Kıbrısçık (Bolu) Sepiolite. MTA Journal 115: 99-118 [in Turkish].

Keller J, Jung D, Eckhardt FJ, Kreuzer H. 1992. Radiometric ages and chemical characterization of the Galatean Andesite Massif, Pontus, Turkey. Acta Vulcanologica 2: 267-276.

Kłusek, M., 2014. Miocene coniferous woods of the Polish Carpathian Foredeep. Acta Palaeontologica Polonica, 59 (3): 697-708.

Kräusel, R., 1920. Nachträge zur Tertiärflora Schlesiens II. Braunkohlenhölzer. Jahrbuch der preußischen geologischen Landesanstalt, 39: 418-460.

Kräusel, R., 1949. Die fossilen Koniferen-Hölzer (Unter Ausschluß von Araucarioxylon Kraus). II: Kritische Untersuchungen zur Diagnostik lebender und fossiler Koniferen-Hölzer. Palaeontographica B, 89:83-203.

Özgüven-Ertan, K., 1971. Sur un bois fossile de Taxodiaceae dans la flore Neogene d'Istanbul (Turquie d'Europe): Sequoioxylon egemeni n.sp. Rev Fac Sci l'Université d'Istanbul, 36 (B): 89-114.

Özgüven-Ertan, K., 1977. La stucture D'une Cupressaceae fossile appartenant au Miocene Trouvee dans la region D'egee en Turquie: Cupressinoxylon akdiki n.sp. Rev Fac Sci l'Université d'Istanbul, 42 (B1-2): 1-15.

Özgüven-Ertan, K., 1981 [1983]. Sequoioxylon gypsaceum (Göeppert) Greguss bois fossile du Tertiaire D'Ankara -Beypazarı (Turquie). Rev Fac Sci l'Université d'Istanbul, 46 (B): 21-28.

Philippe, M. \& Bamford, M.K. 2008. A key to morphogenera used for Mesozoic conifer-like woods. Review of Palaeobotany and Palynology 148: 184207.
Ruiz, D.P. \& Bodnar, J., 2019. The oldest record of Juniperoxylon, a cupressaceous fossil wood from the Middle Triassic of Argentina. Acta Palaeontologica Polonica, 64 (3): 481-488.

Şanlı, İ., 1982. Récherches xylologiques sur la flore du Tertiaire de la Thrace Turque. Review of the Faculty of Forestry University of Istanbul, 32 (A): 84-138.

Stockmans, F. \& Willière, Y., 1934. Notes sur des bois fossiles récoltés en Belgique. Bulletin du Musée royal des sciences naturelles de Belgique 10: 1-8.

Stopes, M.C., 1915. Catalogue of the Mesozoic Plants in the British Museum (Natural History). Part II: Lower Greensand (Aptian) Plants of Britain. xxxvi + 360 pp. Trustees of British Museum, London.

Süss, H. \& Rathner, U., 1998. Ein neues fossiles Holz, Juniperoxylon wagneri sp. nova, aus der miozänen Braunkohle von Wetro (Oberlausitz/Sachsen, Deutschland). Feddes Repertorium 109: 15-24.

Toprak, V., Savasçın, Y., Güleç, N. \& Tankut, A. 1996. Structure of the Galatia volcanic province. International Geology Review. 38: 747-758.

Türkecan, A., Dinçel, A., Hepşen N., Papak, L., Akbaş, B., Sevin, M., Özgür, I. B., Bedi, Y., Mutlu, G., Sevin, D., Ünay, E., Saraç, G. \& Karataş, S. 1991. Stratigraphy and petrology of Neogene volcanics between Bolu-Çankırı (Köroğlu Dağlan). Turkey Geological Congress Bulletin, 6: 85-103 [in Turkish].

van der Burgh, J., 1973. Hölzer der niederrheinischen braunkohlenformation, 2 . Hölzer der braunkohlengruben "Maria Theresia" zu herzogenrath, "Zukunft West" zu eschweiler und "Victor" (Zülpich mitte) zu Zülpich. Nebst einer systematisch-anatomischen bearbeitung der gattung Pinus L. Review of Palaeobotany and Palynology, 15 12: 73-275.

Watari, S. \& Nishida, M., 1973. A Juniperoxylon from the Tertiary of Hokkaido. Journal of Japanese Botany 48: 154-159.

Yağmurlu, F., Helvacı, C, İnci, U. \& Önal, M. 1987. Tectonic features to structural of the Beypazarı and Nallıhan, Central Anatolia, Middle East Technical Univ., 20.4 